\title{
ACCUMULATION AND MOBILE FORMS OF SOME HEAVY METALS IN ROADSIDE URBAN SOILS
}

\author{
Bogdan Nikolov ${ }^{1}$, Slaveya Petrova ${ }^{2}$, Iliana Velcheva ${ }^{3}$, Nikola Angelov ${ }^{4}$, \\ Ekaterina Valcheva ${ }^{5}$, Penka Zapryanova ${ }^{6}$, Gergana Hristozova ${ }^{7}$, Evelina Varbanova ${ }^{8}$, \\ Deyana Georgieva ${ }^{9}$, Violeta Stefanova ${ }^{10}$
}

\begin{abstract}
The accumulation of heavy metals and toxic elements in the topsoil horizon of urban areas is a big environmental problem as they could have long-term implications not only for the soils themselves but also on the human health and wellbeing. Many studies have shown that there is a clear relationship between the level of urbanization, volume of traffic, intensity of anthropogenic activities and heavy metal load.

We aimed to analyze the accumulation of heavy metals at urban roadside soils and to assess the proportion of their mobile forms. The total content and mobile forms of $\mathrm{Cu}, \mathrm{Mn}, \mathrm{Pb}$ and $\mathrm{Zn}$ in soils samples collected along the main boulevards of Plovdiv (Bulgaria) was determined by two instrumental methods - ICP-OES and ICP-MS.

The maximal concentrations were found in the Central and Eastern administrative regions of the city of Plovdiv. This finding well correlated with the wind rose characteristics and urban gradient theory. Our results revealed that the mobile forms of Mn represented 1.38-2.21\% of total content and the mobile forms of $\mathrm{Zn}$ represented 8.48-11.81\% of total content in studied urban soils. Mobile forms of $\mathrm{Cu}$ and $\mathrm{Pb}$ varied significantly and were in the range of 7.04-14.2\% and 7.3-18.67\% of the total content, respectively.
\end{abstract}

UDC Classification: 5(504), DOI: https://doi.org/10.12955/pns.v1.123

Keywords: traffic pollution, urban environment, vegetation, soil properties, toxic elements

\section{Introduction}

Accumulation of heavy metals and toxic elements into soil surface layers is particularly visible in urban areas which are intensively managed by humans (Walczak et al., 2011). A wide range of substances being produced through combustion of fuels, abrasion of vehicle exploitation materials (mainly tires), road de-icing, and industrial processes are emitted to the urban environment. These are mainly toxic gases and dust enriched with heavy metals. Such contamination undergoes dry and wet atmospheric deposition and penetrates into soils (Mcbride et al., 2014; Shang et al., 2012). The transformed structure and chemistry of soils may lead to serious disturbances in their physio-chemical properties, biological activity and functioning, as well to the impoverishment of vegetation cover (Hu et al., 2013; Mao et al., 2014; Nikolov et al., 2019; Swiercz \& Zajecka, 2018; Wu, 2014). It is widely considered that the chemical forms of heavy metals determine their mobility in soil and their bioavailability, hence they determine also and the strength of their toxicity (Doichinova et al., 2014; Lu et al., 2003).

Urban areas occupy only about $5 \%$ of the Earth, but indeed many people live in them (Johnson et al., 2011). Urban soils reflect the impact of different anthropogenic activities on the environment as they represent a medium which is more sustainable in time and space than air or water, thus their ecological

\footnotetext{
${ }^{1}$ Plovdiv University „Paisii Hilendarski“, Faculty of Biology, Department of Ecology and Environmental Conservation, Plovdiv, Bulgaria, nikolov81bg@yahoo.com

2 Plovdiv University „Paisii Hilendarski“, Faculty of Biology, Department of Ecology and Environmental Conservation, Plovdiv, Bulgaria, sl.petrova@abv.bg

${ }^{3}$ Plovdiv University „Paisii Hilendarski“, Faculty of Biology, Department of Ecology and Environmental Conservation, Plovdiv, Bulgaria, anivelcheva@abv.bg

${ }^{4}$ Plovdiv University „Paisii Hilendarski“, Faculty of Biology, Department of Ecology and Environmental Conservation, Plovdiv, Bulgaria, angelov9444@gmail.com

${ }^{5}$ Agricultural University, Faculty of Plant Protection and Agroecology, Department of Agroecology and Environmental Protection, katia_valcheva@abv.bg

${ }^{6}$ Agricultural University, Faculty of Plant Protection and Agroecology, Department of Agroecology and Environmental Protection, p_alexieva@abv.bg

${ }^{7}$ Agricultural University, Faculty of Plant Protection and Agroecology, Department of Agroecology and Environmental Protection, gerihris2@gmail.com

${ }^{8}$ Plovdiv University „Paisii Hilendarski“, Faculty of Chemistry, Department of Analytical Chemistry and Computer Chemistry, Plovdiv, Bulgaria, evarbanova@uni-plovdiv.bg

${ }^{9}$ Plovdiv University „Paisii Hilendarski“, Faculty of Chemistry, Department of Analytical Chemistry and Computer Chemistry, Plovdiv, Bulgaria, georgieva@uni-plovdiv.bg

${ }^{10}$ Plovdiv University „Paisii Hilendarski“, Faculty of Chemistry, Department of Analytical Chemistry and Computer Chemistry, Plovdiv, Bulgaria, stefanova@uni-plovdiv.bg
} 
properties could correlate with the quality of life for the population (Tarzia et al., 2002). A large number of researchers have reported that the type of land use as well as the type of land cover are crucial for sustainable management of soils and their properties. However, there is still a lack of sufficient knowledge as a scientific basis for understanding the urban soil biogeochemistry, so such studies from different urban areas are very useful (Mao et al., 2014). One of the main goals of environmental geochemistry now is to track the abundances of chemical elements in the urban soils, to explain their genesis and to distinguish the lithogenic, pedogenic and anthropogenic inputs (Alekseenko \& Alekseenko, 2014).

Many studies have shown that there is a clear relationship between level of urbanization, volume of traffic, intensity of anthropogenic activities and heavy metals load (Pfeiffer et al., 1991; Albasel \& Cottenie, 1985; Zheng et al., 2002). The survey on the accumulation of heavy metals in the soils of urban green spaces in Seville, Spain, revealed an exceedance of $\mathrm{Pb}, \mathrm{Zn}$ and $\mathrm{Cu}$ in comparison with the hygiene norms (Madrid et al., 2002). The study of large parks in Stara Zagora (Bulgaria) proved technogenic loads on soils with heavy metals on the bases of technogenic coefficients and coefficient of abnormality but without risks for ecosystems (Petkov et al., 2010).

Soils surveyed in the city of Skarżysko-Kamienna (Poland) indicated the exceeded values for heavy metal concentrations, especially $\mathrm{Pb}$ and $\mathrm{Zn}$, which may have an anthropogenic background (Swiercz \& Zajecka, 2018). After detailed analyses, some point sources of soil contamination with these chemical elements have been established. At the same time, a higher content of heavy metals was reported for the soils of industrial areas, rather than for those of urban allotment gardens and urban green areas.

Links between soil pollution with heavy metals and age of the park are determined also (Li et al., 2001; Hou et al., 2015). Increased accumulation of $\mathrm{Cd}, \mathrm{Cu}, \mathrm{Pb}, \mathrm{Zn}$ and other heavy metals was observed in the soil of the old city parks located in commercial and industrial areas, and this is attributed to the automobile and industrial activities in the areas (Du et al., 2013). Recent research in some of the oldest urban parks of Sofia revealed that lead was imported to the soils mainly through dust particles (particulate matter) and accumulated in the surface layers of soil from urban parks (Kachova \& Atanassova, 2017). The data on the chemical variability in the total $\mathrm{Cu}$ and $\mathrm{Cd}$ concentrations confirmed that $\mathrm{Cd}$ and $\mathrm{Pb}$ are inferred as markers of anthropogenic pollution, $\mathrm{Cu}$ contents are attributed to litho(pedo)genic sources, while $\mathrm{Zn}$ is both of anthropogenic and litho(pedo)genic origin.

Based on the above mentioned, we aimed to analyze the accumulation of heavy metals in urban roadside soils and to assess the proportion of their mobile forms.

\section{Data and methodology}

\section{Study area}

The city of Plovdiv is located at $24^{\circ} 45^{\prime}$ east longitude and $42^{\circ} 09^{\prime}$ north latitude, at an altitude of $160 \mathrm{~m}$ a.s.l. It is the second largest city in Bulgaria after Sofia and is also one of the most densely populated cities in the country with almost 350,000 inhabitants per $102 \mathrm{~km}^{2}$ (NSI, 2018). According to the General plan of the territory of Plovdiv (2007), the city's area is divided into six administrative regions Northern, Eastern, Southern, Western, Central, Trakiya. Within the city are located six syenite hills, some industrial zones, compact central zone, some suburbs, wide network of busy streets and boulevards, two train tracks, several big and many smaller green areas.

\section{Sample collection}

Soil samples were taken in March 2019 from areas situated along the main boulevard in each of the administrative regions (Fig. 1). The material was collected on the depth of $0-20 \mathrm{~cm}$ and each sample was formed by five subsamples (Petrova et al., 2013).

\section{Laboratory analyses}

The $\mathrm{pH}$ of the collected roadside soil samples was measured using a pHotoFlex Set, 2512000, WTWGermany.

The total content of the studied metals $(\mathrm{Cu}, \mathrm{Mn}, \mathrm{Zn}$ and $\mathrm{Pb})$ in air dried soil samples was estimated after MW digestion in closed PTFE vessels (ETHOS ONE, Milestone) by using a mixture of $\mathrm{HNO}_{3}+\mathrm{H}_{2} \mathrm{O}_{2}$. The extraction of mobile forms was performed according the ISO 14870 method. All reagents used for both sample preparations are high purity analytical grade. For a control of possible contamination due 
to the regents or sample preparation procedure, balk samples are prepared and analyzed for every sample batch.

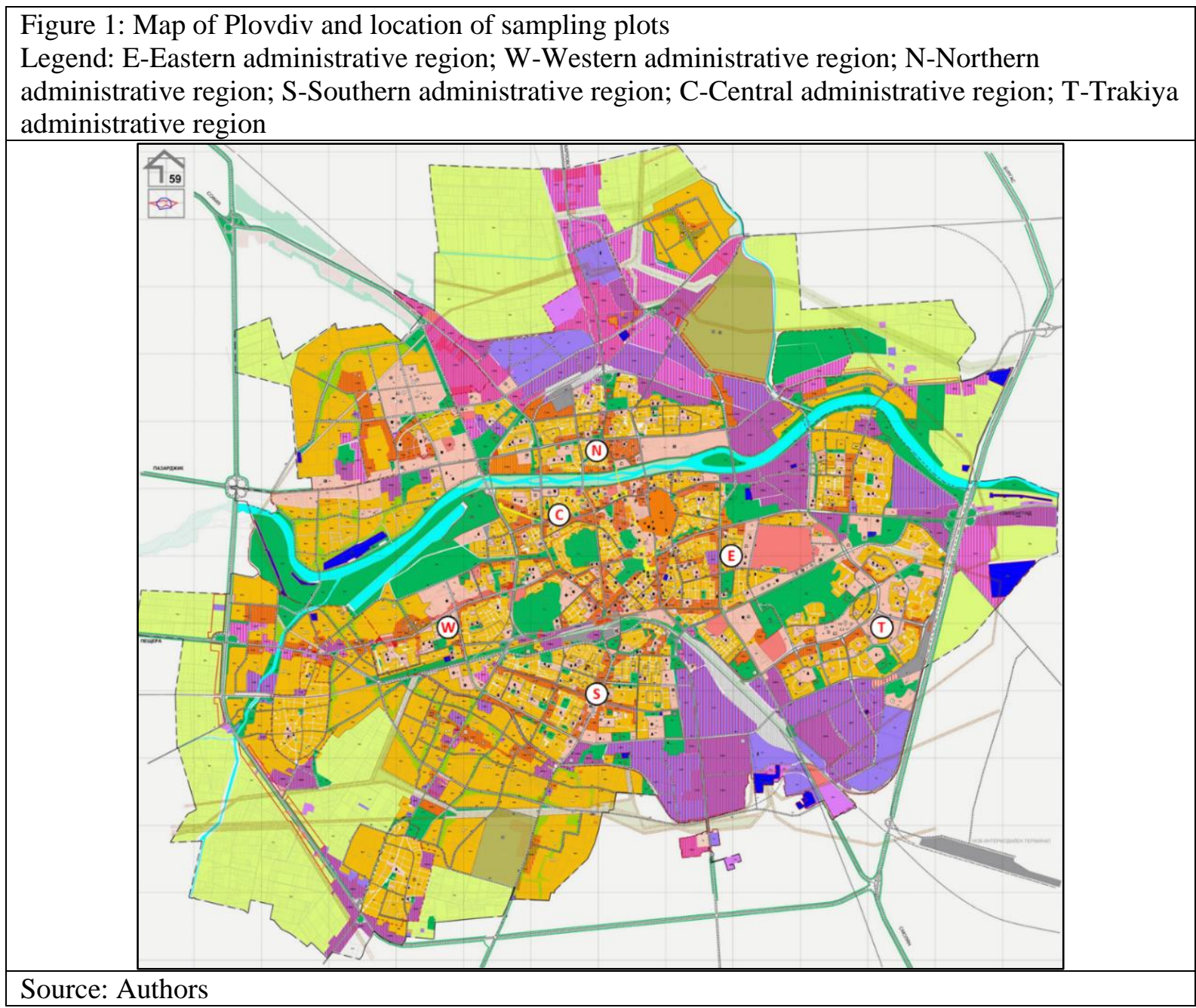

Two ICP based analytical techniques were used for the determination of the total content and mobile forms. The total content of $\mathrm{Cu}(324.754 \mathrm{~nm}), \mathrm{Mn}(348.291 \mathrm{~nm}), \mathrm{Zn}(206.200 \mathrm{~nm})$ and $\mathrm{Pb}(220.353 \mathrm{~nm})$ was determined by ICP-OES (iCAP 6300 Duo,S, Thermo Scientific) at the appointed spectral lines by axial plasma observation with an exception of $\mathrm{Mn}$ ( for which radial plasma view mode was used). Inductively Coupled Plasma Mass Spectrometer (ICP-MS Agilent 7700 Tokyo, Japan) with octopole reaction system (ORS) and helium as collision gas was used for the determination of the mobile forms. The following isotopes were monitored: ${ }^{54} \mathrm{Mn},{ }^{63} \mathrm{Cu},{ }^{65} \mathrm{Cu},{ }^{64} \mathrm{Zn},{ }^{66} \mathrm{Zn},{ }^{206} \mathrm{~Pb}$ and ${ }^{208} \mathrm{~Pb}$.

The calibration solutions were prepared after appropriate dilution of Multi VI (30 elements in $\mathrm{HNO}_{3}$, Merck, Darmstadt, Germany), traceable to NIST. For on-line correction of non-spectral matrix effect in ICP-MS ${ }^{103} \mathrm{Rh}$ was used as an internal standard. Both instrumental methods are validated via analysis of a certified reference material (CRM) Loam Soil ERM ${ }^{\circledR}$ - CC141. The same material was used for quality control purposes. A portion of CRM was digested and analyzed together with samples.

The measured concentrations of all tested elements were statistically comparable with the declared certified values (for extraction with Aqua Regia). Data were presented as mean values in $\mathrm{mg} / \mathrm{kg}$ with corresponding expanded uncertainties $(\mathrm{k}=2)$.

\section{Statistical analyses}

A descriptive analysis was obtained using the following variables: mean, median, range (minimum and maximum), standard deviation, and coefficient of variation. In order to test the differences of elemental concentrations, both between total content and mobile forms of studied elements in urban soils from six administrative regions, a t-test was performed $(\mathrm{p}<0.05)$. In order to analyze the relationship between the total content and mobile forms of studied elements a linear regression analysis was used $(p<0.05)$. 


\section{Results and Discussion}

Based to their genesis, the soils in the Plovdiv area are classified as Fluvisol according to FAO World Reference Base for Soil Resources (2014). Due to the prolonged human presence on the studied territory (more than 8000 years) and the increasing temps of urbanization in the last decades, soil properties are significantly influenced, and it is more appropriate to discuss them as Technosols (Petrova et al., 2018). Soils from the studied urban roadsides are slightly acidic to neutral with $\mathrm{pH}$ values ranging from 6.23 to 6.7 (Table 1). The soils were characterised with a small $\mathrm{pH}$ variation as evidenced by the calculated coefficients of variation. Our data well correspond with the findings of Golcz et al. (2014), as well as Dzierżanowski \& Gawroński (2011), that urban areas have either neutral or alkaline pH. Physiochemical properties of urban soils depend on the geological characteristics of substrate as well as the properties and structure of the urban environment (Greinert, 2015). As noted by Park et al. (2010), physio-chemical properties of soils are derivatives of the city age and spatial structure. Here they include factors influencing soils in various stages of urban development and concerns both industry and transportation growth, as well as the intensity of urbanisation. Moreover, soils are subject to numerous land-use treatments and thus unequivocally transform their structure and physio-chemical properties.

The content of heavy metals in the studied urban soils reflect the variability of $\mathrm{Cu}, \mathrm{Mn}, \mathrm{Pb}$ and $\mathrm{Zn}$ both as total content and mobile forms (Table 1). The highest total content of $\mathrm{Pb}$ and $\mathrm{Zn}$ was reported for the Eastern administrative region of Plovdiv, while for Mn, maximums were found in the Northern and Central administrative regions. $\mathrm{Cu}$ content was quite similar $(49-56 \mathrm{mg} / \mathrm{kg})$ in four administrative regions and significantly lower in the others $(32-36 \mathrm{mg} / \mathrm{kg})$. These findings could be related to the city's specific topography and the wind rose characteristics - the prevailing winds in the year are from the West to East, rarely from the South, so they blow the pollutants to the Central and Eastern regions. On the northern side of the city is situated the North Industrial Area, and to the southern side is located one of the biggest non-ferrous plant on the Balkan Peninsula - KCM 2000 LTD. Their contribution to the urban air pollution could be significant in some cases (Petrova et al., 2013).

The highest coefficients of variation were noted for $\mathrm{Pb}-0.44$ for total content and 0.58 for mobile forms. As a whole, all studied elements showed a higher coefficient of variation of mobile forms in comparison to the variation of total content. An exception was found only for Mn, where soil content of the mobile forms does not vary as much as the total content. This could be due to its stronger retention in soil complex and its weaker extraction, respectively.

\begin{tabular}{|c|c|c|c|c|c|c|c|c|c|c|c|c|c|}
\hline \multirow[b]{2}{*}{$\begin{array}{c}\text { Roadside } \\
\text { soil } \\
\text { sample }\end{array}$} & \multirow[b]{2}{*}{ pH } & \multicolumn{3}{|c|}{$\mathbf{C u}$} & \multicolumn{3}{|c|}{ Mn } & \multicolumn{3}{|c|}{$\mathbf{P b}$} & \multicolumn{3}{|c|}{$\mathbf{Z n}$} \\
\hline & & Total & $\begin{array}{l}\text { Mobile } \\
\text { forms }\end{array}$ & $\begin{array}{l}\% \text { of } \\
\text { total }\end{array}$ & Total & $\begin{array}{l}\text { Mobile } \\
\text { forms }\end{array}$ & \begin{tabular}{|c|}
$\%$ \\
of \\
total
\end{tabular} & Total & $\begin{array}{l}\text { Mobile } \\
\text { forms }\end{array}$ & $\begin{array}{l}\% \text { of } \\
\text { total }\end{array}$ & Total & $\begin{array}{l}\text { Mobile } \\
\text { forms }\end{array}$ & $\begin{array}{l}\text { \% of } \\
\text { total }\end{array}$ \\
\hline $\mathbf{E}$ & 6.46 & 50 & 7.1 & 14.2 & 508 & 8.2 & 1.61 & 100 & 17.0 & 17.0 & 160 & 16.0 & 10.0 \\
\hline W & 6.23 & 36 & 3.2 & 8.88 & 524 & 8.0 & 1.53 & 56 & 8.9 & 15.89 & 141 & 13.0 & 9.22 \\
\hline $\mathbf{N}$ & 6.33 & 56 & 5.8 & 10.36 & 691 & 9.5 & 1.38 & 52 & 6.8 & 13.08 & 127 & 15.0 & 11.81 \\
\hline $\mathbf{S}$ & 6.29 & 32 & 4.1 & 12.81 & 421 & 9.3 & 2.21 & 30 & 5.6 & 18.67 & 74 & 6.9 & 9.32 \\
\hline $\mathrm{C}$ & 6.40 & 54 & 3.8 & 7.04 & 594 & 9.4 & 1.58 & 38 & 4.6 & 12.04 & 99 & 9.1 & 9.19 \\
\hline $\mathbf{T}$ & 6.70 & 49 & 4.1 & 8.37 & 499 & 9.4 & 1.88 & 59 & 5.3 & 8.98 & 79 & 6.7 & 8.48 \\
\hline Mean & 6.40 & 46.17 & 4.68 & 10.28 & 539.5 & 8.97 & 1.70 & 55.87 & 8.03 & 14.28 & 113.3 & 11.12 & 9.67 \\
\hline Median & 6.37 & 49.5 & 4.1 & 9.62 & 516.0 & 9.35 & 1.60 & 54.0 & 6.2 & 14.49 & 113.0 & 11.05 & 9.27 \\
\hline Min & 6.23 & 32.0 & 3.2 & 7.04 & 421.0 & 8.0 & 1.38 & 30.0 & 4.6 & 8.98 & 74.0 & 6.7 & 8.48 \\
\hline Max & 6.7 & 56.0 & 7.1 & 14.2 & 691.0 & 9.5 & 2.21 & 100.0 & 17.0 & 18.67 & 160.0 & 16.0 & 11.81 \\
\hline SD & 0.17 & 9.85 & 1.47 & 2.75 & 92.56 & 0.68 & 0.30 & 24.31 & 4.64 & 3.57 & 34.82 & 4.09 & 1.15 \\
\hline $\begin{array}{l}\text { Coeff. of } \\
\text { variation }\end{array}$ & 0.03 & 0.21 & 0.31 & 0.27 & 0.17 & 0.08 & 0.18 & 0.44 & 0.58 & 0.25 & 0.31 & 0.38 & 0.12 \\
\hline
\end{tabular}

Source: Authors

The median values of almost all soil samples for $\mathrm{Pb}$ were lower in comparison with the median value specified for the urban soils from 34 European cities (102 mg/kg d.m.) (Luo et al., 2012), except roadside soil from the Eastern administrative region which had a similar $\mathrm{Pb}$ content. Lead belongs to those toxic chemical elements which are released due to emission of car exhaust fumes (Ferreira et al., 2016). Our data were significantly lower in comparison to the values recorded for the green areas located in the city 
centre of Skarżysko-Kamienna (Poland) which were similar to those observed for its suburbs (Świercz\& Zajęcka, 2018).

Copper is a chemical element widely distributed in nature, and its content in urban soils is involved in many processes. The main sources of this heavy metal are emissions of car exhaust fumes as well as abrasion of car tire treads and road surfaces (Ferreira et al, 2016). Our results for total $\mathrm{Cu}$ content were quite similar to the mean value for European cities - $46 \mathrm{mg} / \mathrm{kg} \mathrm{d.m.} \mathrm{(Luo} \mathrm{et} \mathrm{al.,} \mathrm{2012)} \mathrm{and} \mathrm{also} \mathrm{to} \mathrm{the}$ data reported for the city centre of Skarżysko-Kamienna (Poland) (Świercz\& Zajęcka, 2018).

The Zn concentrations in our study ranged from $74-160 \mathrm{mg} / \mathrm{kg}$ with a median of $113 \mathrm{mg} / \mathrm{kg}$, while the median for European cities amounted to $130 \mathrm{mg} / \mathrm{kg} \mathrm{d.m}$. (Luo et al., 2012). Zinc may be released from anti-corrosion coatings as well as directly from transported goods (Ferdeous \& Manalo, 2014). Anthropogenic enrichment of areas lying along railways in $\mathrm{Zn}$ is also noted by Wiłkomirski et al. (2011) in the studies conducted in the areas of a railway station in the town of Ilawa (Poland). Our previous studies on the territory of the city of Plovdiv have shown that $\mathrm{Zn}$ in soils is both of anthropogenic and litho(pedo)genic origin (Nikolov et al., 2019).

Soil accumulation of heavy metals in urban areas is closely related to the emission of car exhaust fumes and abrasion of brake components (Doležalová Weissmannová et al., 2015). Analysis of correlation coefficients may contribute to the identification of relationships among the analysed heavy metals, as well as indicate their sources and common origins (Salah et al., 2015). The correlation coefficient at a level of $>0.7$ indicates extremely strong relationships among the analysed pairs of data (Pam et al., 2011). In our study, we found two pairs of elements with high correlation coefficients: $\mathrm{Cu}-\mathrm{Mn}(\mathrm{R}=0.77)$ and $\mathrm{Pb}-\mathrm{Zn}(\mathrm{R}=0.75)$. The close relationships could be successfully used for better understanding the genesis of heavy metals and the factors to their migration. The studies conducted by Salah et al (2015) suggest that $\mathrm{Cu}, \mathrm{Pb}$ and $\mathrm{Zn}$ belong to the group of lithologically related heavy metals. Significant correlation among these heavy metals may indicate their natural origins associated with the chemistry of parent rocks. However, Doležalova Weissmannova et al. (2015) and Hu et al. (2013) point out that the given linear relationships among heavy metals in urban soils may be a derivative of environmental pressure and anthropogenic enrichment in heavy metals. Doležalova Weissmannova et al. (2015) notice strong relationships among $\mathrm{Cu}-\mathrm{Cd}$ and $\mathrm{Pb}-\mathrm{Zn}-\mathrm{Cu}$ in the soils of Ostrava (Czech Republic), while $\mathrm{Hu}$ et al. (2013) obtain relationships among $\mathrm{Zn}-\mathrm{Cu}, \mathrm{Cd}-\mathrm{Pb}$ and $\mathrm{Zn}-\mathrm{Pb}$ in the soils of Guangdong Province (China).

The regression trend line shows a strong relationship between the total and mobile forms of $\mathrm{Pb}$ and $\mathrm{Zn}$ in urban soils (Fig. 2). The $\mathrm{R}^{2}$ values show that $83 \%$ and $91 \%$ of the variance in mobile forms of $\mathrm{Pb}$ and $\mathrm{Zn}$ respectively is explained by the variance of their total content.

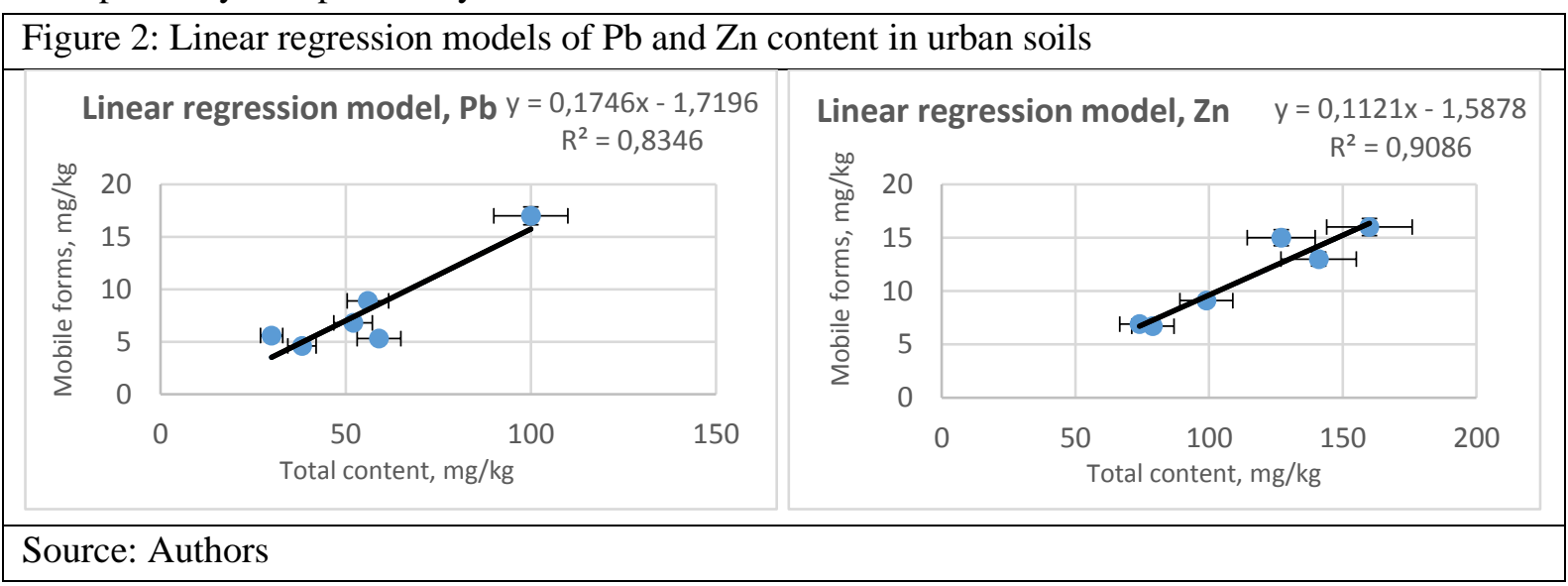

\section{Conclusion}

The maximal concentrations of studied elements in urban soils were found in the Central, Northern and Eastern administrative regions of the city of Plovdiv. This finding well correlated with the wind rose characteristics and urban gradient theory. Our results revealed that the mobile forms of $\mathrm{Mn}$ represented $1.38-2.21 \%$ of total content and the mobile forms of $\mathrm{Zn}$ represented $8.48-11.81 \%$ of total content in studied urban soils. Mobile forms of $\mathrm{Cu}$ and $\mathrm{Pb}$ varied significantly and were in the range of 7.04-14.2\% and $7.3-18.67 \%$ of the total content, respectively. The highest coefficients of variation were noted for 
$\mathrm{Pb}-0.44$ for total content and 0.58 for mobile forms. As a whole, all studied elements showed higher coefficients of variation of mobile forms in comparison with the variation of total content.

\section{Acknowledgements}

This research work was carried out with the support of the National Scientific by contract KP 06 OPR 03/12, managed by Prof. Iliana Velcheva, University of Plovdiv "Paisii Hilendarski".

\section{References}

Albasel, N., \& Cottenie, A. (1985). Heavy metal contamination near major highways, industrial and urban areas in Belgian grassland. Water Air and Soil Pollution, 24, 103-109.

Alekseenko, V., \& Alekseenko, A. (2014). The abundances of chemical elements in urban soils. Journal of Geochemical Exploration, 147, 245-249.

Doichinova, V., Zhiyanski, M., A., \& Bech, J. (2014). Study on mobility and bioavailability of PTEs in soils from Urban Forest Parks in Sofia. Bulgaria. Journal of Geochemical Exploration, 147(B), 222-228.

Doležalová Weissmannová, H., Pavlovský, J., \& Chovanec, P. (2015). Heavy Metal Contaminations of Urban Soils in Ostrava, Czech Republic: Assessment of Metal Pollution and Using Principal Component Analysis. International Journal of Environmental Research, 9, 683-696.

Du, Y., Gao, B., Zhou, H., Ju, X., Hao, H., \& Yin, S. (2013). Health risk assessment of heavy metals in street dusts in urban parks of Beijing, China. Procedia Environmental Sciences, 18, 299-309

Dzierżanowski, K., \& Gawroński, S. (2011). Analysis of Heavy Metals Content in Soil and Dandelion Leaves in the Vicinity of a Busy Urban Street Using a Handheld xrf Spectrometer. Environmental Protection and Natural Resources, 50, $202-211$.

FAO. 2014. World Reference Base for Soil Resources. Retrieved from http://www.fao.org.

Ferdeous, A., \& Manalo, A. (2014). Failures of Mainline Railway Sleepers and Suggested Remedies - Review of Current Practice. Engineering Failure Analysis, 44, 17-35.

Ferreira, A.J.D., Soares, D., Serrano, L.M.V., Walsh, R.P.D., Dias-Ferreira, C. \& Ferreira, C.S. (2016). Roads as Sources of Heavy Metals in Urban Areas. The Covões Catchment Experiment, Coimbra, Portugal. Journal of Soils and Sediments, 16(11), 1-18.

General plan of the territory of Plovdiv. 2007. Retrieved from https://www.plovdiv.bg/wpcontent/uploads/2013/08/OUP_2.jpg

Golcz, A., Kozik, E., Golcz-Polaszewska, M., Kościelniak, K., \& Musił, N. (2014). Soils and Plants in the Nadolnik Park in Poznań. Part I Physical and Chemical Properties of Soils and the Content of Macroelements in Plants. Science, Nature and Technology, 8(3), 1-13 (in Polish).

Greinert, A. (2015). The Heterogeneity of Urban Soils in the Light of their Properties. Journal of Soils and Sediments, 15(8), $17-25$.

Hou, E., Xiang, H., Li, J., \& Wen, D. (2015). Soil Acidification and Heavy Metals in Urban Parks as Affected by Reconstruction Intensity in a Humid Subtropical Environment. Pedosphere, 25, 82-92.

Hu, Y., Liu, X., Bai, J., Shih, Y., Zeng, E.Y., \& Cheng, H. (2013). Assessing Heavy Metal Pollution in the Surface Soils of a Region that Had Undergone Three Decades of Intense Industrialization and Urbanization. Environmental Science and Pollution Research, 20(9), 6150-6159.

Johnson, C., Demetriades, A., J., \& Ottesen, R.T. (Eds.). (2011). Mapping the Chemical environment of Urban areas. UK: John Wiley \& Sons Publishing House.

Kachova, V., \& Atanassova, I. (2017). Heavy metal pools in urban soils from city parks of Sofia, Bulgaria. Agricultural science and technology, 9(2), 144-150.

Li, N., Poon, C., \& Liu, P. (2001). Heavy metal contamination of urban soils and street dusts in Hong Kong. Applied Geochemistry, 16, 1361-1368

Lu, Y., Gong, Z. T., Zhang, G. L., \& Burghardt, W. (2003). Concentrations and chemical speciations of $\mathrm{Cu}, \mathrm{Zn}, \mathrm{Pb}$ and $\mathrm{Cr}$ of urban soils in Nanjing, China. Geoderma, 115, 101-111.

Luo, X.S., Yu, S., Zhu, Y.G., \& Li, H.D. (2012). Trace Metal Contamination in Urban Soils of China. Science of the Total Environment, 421-422, 17-30.

Madrid, L., Diaz Barrientos, F., \& Madrid, F. (2002). Distribution of Heavy Metal Contents of Urban Soils in Parks of Seville. Chemosphere, 49(10), 1301-1308.

Mcbride, M.B., Shayler, H.A., Spliethoff, H.M., Mitchell, R.G., Marquez, L.G., Ferenz, G.S., Russel, J.M., A.L., \& Bachman, S. (2014). Concentrations of Lead, Cadmium and Barium in Urban Garden Grown Vegetables: The Impact of Soil Variables. Environ. Pollution, 194, 254-261.

National Statistics Institute (NSI). (2018). Retrieved from http://www.nsi.bg.

Nikolov, B., Velcheva, I., Zheleva, E., Zaprianova, P., Valcheva, E., Bileva, T., \& Petrova, S. (2019). Accumulation of Heavy Metals in the Urban Soils of Natural Monument "Bunardzhik" (Plovdiv, Bulgaria). Ecologia Balkanica, 11(2), 215 228. 
Pam, E., Akiti, T., Osae, S., Ganyaglo, S., \& Gibrilla, A. (2011). Multivariate Cluster Analysis of Some Major and Trace Elements Distribution in an Unsaturated Zone Profile, Densu River Basin, Ghana. African Journal of Environmental Science and Technology, 5, 155-167.

Park, S.J., Zhiqiang, C., Hanbae, Y., Morris, E.E., Sutherland, M., Mcspadden Gardener, B.B., \& Grewal, P.S. (2010). Differences in Soil Chemical Properties with Distance to Roads and Age of Development in Urban Areas. Urban Ecosystems, 13(4), 483-497.

Petkov, G., Yablanski, Ts., Todorova, M., D., Kostadinova, G., \& Barakova, V. (2010). Ecological Assessment of Soils from Parks and Places in Stara Zagora. Ecology and Future, IX, 4, 24-32

Petrova, S., Yurukova, L., Velcheva, I. (2013). Taraxacum officinale as a biiomonitor of metals and toxic elements (Plovdiv, Bulgaria). Bulgarian Journal of Agricultural Science, 18(5), 742-748.

Petrova, S., Nikolov, B., Velcheva, I., Yankova, M., Kogan, E., Zheleva, E., Valcheva, E., A., Marhova, M., Tsankova, M., \& Iliev, I. (2018). Dynamics of soil properties under a pollution gradient in urban areas (Plovdiv, Bulgaria). Scientific Papers, Series A. Agronomy, LXI, 1, 109-116.

Pfeiffer, E.M., Freytag, J., \& Scharpenseel, H.W. (1991). Investigation of heavy metal and arsenic pollution of soils and plants in the urban area of Manila, Philippines. Mitteilungen der Deutschen Bodenkundlichen Gesellschaft, 66, 1169-1172.

Salah, E.A., Turki, A.M., \& Mahal, S.N. (2015). Chemometric Evaluation of the Heavy Metals in Urban Soil of Fallujah City, Iraq. Journal of Enironmental Protection, 6(11), 1279-1292.

Shang, L.Y., Sun, R.H., Wang, Z.M., Ji, Y.H., \& Chen, L.D. (2012). Assessment of Heavy Metal Pollution in Surface Sediments of Rivers in Northern Area of Haihe River Basin. China Journal of Environmental Sciences, 33, 606-611.

Swiercz, A., \& Zajecka, E. (2018). Accumulation of heavy metals in the urban soils of the city of Skarżysko-Kamienna (Poland) with regard to land use. Carpathian Journal of Earth and Environmental Sciences, 13(1), 249-266.

Tarzia, M., De Vivo, B., Somma, R., Ayuso, R.A., McGill, R.A.R., \& Parrish, R.R. (2002). Anthropogenic vs. natural pollution: an environmental study of an industrial site under remediation (Naples, Italy). Geochemical Exploration and Environmental Analysis, 2, 45-56.

Walczak, B., Greinert, A., Gosk, L., \& Gorka, K. (2011). Influence of Soil Geomechanical Transformations in Urban Communication Areas on their Physicochemical Properties. Soil Science Annales, 62(2), 412-419.

Wiłkomirski, B., Sudnik-Wójcikowska, B., Galera, H., Wierzbicka, M., \& Malawska, M. (2011). Railway Transportation as a Serious Source of Organic and Inorganic Pollution. Water, Air and Soil Pollution, 218(1-4), 333-345.

Wu, J. (2014). Urban Ecology and Sustainability: The State of-the-Science and Future Directions. Landscape and Urban Planning, 125, 209-221.

Zheng, Y.M., Yu, K., Wu, H.T., Huang, Z.C., Chen, H., Wu, X., Tian, Q.Z., Fan, K.K., \& Chen, T.B. (2002). Lead concentrations of soils in Beijing urban parks and their pollution assessment. Geographical Research, 21, 418-424. 